\title{
Ukanju and the Changing Political Order of Northeastern Asia in the 17th Century*
}

Meng Heng Lee $e^{* *}$

\section{Introduction}

For decades, most historians defined the $u k a n j u$, also known as taoren (逃人) in the Chinese-language archives of the Qing Dynasty (1644-1911 A.C.), as the Manchu's ethnic Han-Chinese slaves or escapees. However, this definition fails to explain why ukanju served as the catalyst for the Manchu invasions of Chosŏn in 1627 and 1636 and why so many ukanju with considerable ethnic diversity emerged in the first half of the 17th century. Also, the question of what roles the ukanju played in the MingQing transition (1616-1644 A.C.) - most related records were in Manchu

* This paper is adapted from my M.A. thesis, "The Repatriation of the Ukanju between the Chosŏn and the Manchu: The Transition of Northeast Asian Political Order in the Seventeenth Century" (National Taiwan University, 2015). I would like to express my gratitude to the editors of the IJKH and three anonymous readers for their shrewd comments and suggestions. All remaining flaws are my sole responsibility. As one of the readers mentions, I seem to over-emphasize ukanju as a general noun rather than the proper noun, resulting in the fact that I am trying to include various groups into a huge general term. It is a fair comment, and I appreciate it. However, since there are numerous usages of the term ukanju in Manchu archives to describe diverse groups of people, I suggest that it is necessary to refer to the term as more a general noun than a proper noun.

** Ph.D. Student, Department of East Asian Languages and Cultures, Columbia University, New York, NY, USA. 
archives - is still unexplored.

In this essay, I will point out the overlooked relationship between the ukanju and the transition of political order in Northeastern Asia during the 17th century. To achieve this goal, I will focus on three themes: the redefining of $u k a n j u$, the rediscovery of the composition of the $u k a n j u$, and the reevaluation of the pivotal role the ukanju played during the tumultuous 17 th century, regarding the widespread war, the collapse of the Ming dynasty, and the rise of the Qing.

For the first theme, based on a brief, critical review of related research, I will offer a new definition of ukanju using the Manchu archives. These archives include Tao Ren Dang (逃人檔), Nei Guo Shi Yuan Dang (內國史 院檔), and Man Wen Lao Dang (滿文老檔). ${ }^{1}$ By utilizing these Manchu archives, I will construct a new picture of the ukanju in comparison with the majority of research based on records that were written in classical Chinese.

Secondly, having reconsidered the meaning of $u$ kanju based on Manchu sources, I will analyze the Manchu archives to understand the social composition of the ukanju. In contrast to the traditional view, which defines ukanju as "escapee" or "fleeing slave," I will explore both the racial ethnic composition and the social status of ukanju. Based on these new

1 Kato Naoto (加藤直人), Tao Ren Dang: Ubašame ukame jihe, museingge ukame genehe dangse (Tao Ren Dang: Early Manchu Archives of Escaped Persons) (Tokyo: Tōhoku Ajia Bunken Kenkyūkai, 2007); Kawachi Yoshihiro (河内良弘), ed., 内国史院満文档案訳註 中国第一歴史档案館蔵:崇徳二 · 三年分 [Annotated Japanese translation of the Neiguoshiyuan dang (Early Manchu archives of the Qing Historiography Academy), the second and third years of Chongde (1637 and 1638)], (Tokyo: Shōkadō Shoten, 2010); Kusunoki Yoshimichi (楠木賢道), ed., 內国史院檔:天聡五年 I (Early Manchu Archives of the Imperial Historiographical Office, the Fifth Year of Tiancong 1: 1631) (Tokyo: Tōyō Bunko, 2011); Kusunoki Yoshimichi (楠木賢道), ed., 內國史院檔:天聰八年 (Early Manchu Archives of the Imperial Historiographical Office, the Eighth Year of Tiancong:1634) (Tokyo: Tōyō Bunko, 2009); Kanda Nobuo (神田信夫), ed., 滿文老檔 (Secret chronicles of the Manchu dynasty, 1607-1637) (Tokyo: Tōyō Bunko, 1956). 
categories of analysis, the complex and divergent composition of the ukanju can be preserved, providing a clearer basis for discussing the influence of the ukanju during the 17 th century.

Finally, I will discuss the crucial role that the ukanju played in the 17th century. In addition to the previous Manchu and Chosŏn archives, for this analysis I have consulted Chosónwangjosillok (朝鮮王朝實錄，The Annals of the Chosón Dynasty) and Sinbosugyochimnok (新補受呚輯錄), as well as other archives from the Qing dynasty, such as Qing Shi Lu (清實錄, The Annals of the Qing Dynasty). By analyzing the records regarding the ukanju from these archives, the significant yet overlooked relationship between the $u k a n j u$ and the changing political order of Northeastern Asia in the 17 th century can be rediscovered.

\section{The Discourse on Ukanju: A Brief Review of Related Research and a New Approach}

To begin the discussion of the ukanju and the political order of Northeast Asia, it is necessary to ask: what, or who, were the $u$ kanju?

The Manchu word ukanju appears to have an easy-to-understand equivalent in Chinese-taoren (逃人), which refers to people (ren, 人) who flee (tao, 逃). Since the meaning of ukanju seems simple in Chinese, many have merely viewed these people as escapees. In one of the earliest research studies regarding taoren, Tao Xi-sheng, a famous historian who was involved in the Chinese Social History Controversy of the 1930s, depicted taoren as escaped slaves (of Manchu), most of whom were ethnic Han-Chinese. ${ }^{2}$ This approach to taoren studies, which was deeply influenced by Marxist theories of history from the early $20^{\text {th }}$ century, maintained prominence in subsequent decades.

From the 1960 s to the 1980 s, most studies on ukanju or taoren still

2 Tao Xi-sheng (陶希聖), “Shun zhi chao de tao ren yu tou chong wen ti (順治朝的 逃人及投充問題), "Shi Huo (食貨) 3, no. 11 (May 1936): 35-44. 
held this conventional view. Most researchers conceded the fact that taoren were Manchu slaves based on the promulgation of a unique law in the $17^{\text {th }}$ century that ruthlessly punished taoren. These researchers, however, disagreed on the ethnic composition of taoren. ${ }^{3}$

Some scholars claimed that taoren were composed of ethnic HanChinese people, others included ethnic Mongols and Koreans, and still others remained ambivalent. ${ }^{4}$ These conflicting views on the racial composition of taoren can be partly attributed to the differences in the classical Chinese materials that each researcher utilized and are rooted in whether or not the researcher believed in a "class struggle" between the Chinese taoren and Manchus, like slaves with their owners. But the more crucial point is their over-reliance on the Chinese term taoren and hence their failure to consider ukanju in Manchu. ${ }^{5}$ It is critical to fully understand the definition of $u k a n j u$ through the records in the Manchu archives.

3 Zhang Jin-fan (张晋藩) and Guo Cheng-kang (郭成康), Qing ru guan qian guo jia fa lu zhi du shi (清入關前國家法律制度史) (Shenyang: Liaoning ren min chu ban she, 1988); Wu Bo-ya (労伯姬), “Lun qing chu tao ren fa de she hui ying xisng (論 清初逃人法的社會影響), " Qing Shi Lun Cong (清史論叢) 3 (February 1982): 1309; Liu Jia-ju (劉家駒), “Shun zhi nian jian de tao ren wen ti (順治年間的逃人問 題), ” in Qing zhu li ji xian sheng qi shi sui lun wen ji 2 (慶祝李濟先生七十歲論文 集 下) (Tai bei shi: Qing hua xue bao she, 1967), 1049-80.

4 Here it should be noted that, recently, Korean academics have also noticed the people who crossed into (or were forced to cross into) Manchuria during the MingQing transition, such as Han Myung-Ki and Woo Kyung-Sup. However, they ignored the link between those border-crossers and ukanju, which is the key to constructing a broader picture of East Asian history in the $17^{\text {th }}$ century that combines Korean history with Chinese history. See Han Myung-Ki, Chŏngmyo, Pyŏngja Horan'gwa Tong Asia (Studies of Manchu's invasions of Chosun Korea in 1627 and 1636 with east asian perspectives) (Seoul: P'urŭn Yŏksa, 2009); Woo KyungSup, "Manjuro Kwihwahan Chosŏnindŭl," in Pŏmwolgwa Isan: Manjuro Kŏnnŏgan Chosŏnindul (Illegal Crossing Border and Seperation), ed. Kim Seonmin (Incheon: Inha Taehakkyo Ch'ulp'anbu, 2010).

5 Haneda Tooru (羽田亨), ed., Man He Ci Dian (滿和辭典) (Taipei: Xue hai, 1998), 445. 
Such an approach has not been applied, which has led to the continuation of the previously mentioned disagreement. Is the definition of ukanju "escaped slave of Manchuria"? What is the ethnic composition of the $u k a n j u$ ? What had the $u k a n j u$ done in the early $17^{\text {th }}$ century? In this essay, I will use published Manchu archives to rediscover the composition of the $u k a n j u$, and, in turn, attempt to shed a new light on their historical significance - the role that the ukanju played in shaping a new political order in Northeast Asia in the $17^{\text {th }}$ century.

\section{Who were the Ukanju? Re-examining the composition of the ukanju}

To understand the $u k a n j u$, one needs to understand the group's composition; to see how the group is composed, one must decipher the different depictions of the $u k a n j u$ and the historical context laid out in the archives. In this section, I will use the aforementioned Manchu archives to reexamine the composition of the ukanju.

1. The Ethnic Composition of the Ukanju

\section{1) Mongol Ukanju}

Mongolians accounted for a significant percentage of all $u k a n j u$ in the early $17^{\text {th }}$ century, especially during the reign of Nurhaci. The following record in 1620 in Man Wen Lao Dang illustrates the existence of the Mongol ukanju and their characteristics:

One man belonging to Taiji Sonin of Bayot [a Mongolian tribe] rode cattle and fled to us. Apprehended, this man was allocated to efu Enggeder. Another man belonging to jaisang Keoken of Jarut [a Mongolian tribe] rode a horse and fled to us. Apprehended, this man was allocated to beile Bak. So as not to break the solemn vow 
which we took with Mongol aristocrats, we decided to repatriate these two ukanju, who fled to us after the vow was taken. ${ }^{6}$ (emphasis mine)

This record points out four characteristics regarding these $u k a n j u$. First, the $u k a n j u$, although an individual person, belonged to someone else. Second, ukanju referred to people who fled (towards Manchuria). Third, $u k a n j u$ should be repatriated (to the owner) or allocated to others. Fourth, Mongol ukanju existed, and were specifically fleeing towards Manchuria. This last fact dispels the myth that ukanju, or taoren in Chinese, were only composed of Chinese people. However, is it fair to say that an $u k a n j u$ is equivalent to a slave due to its approximation to property rather than a free person? To answer this question, we must take a look at the case of Chinese $u k a n j u$, who have been construed as Manchu slaves for at least half a century.

\section{2) Han-Chinese Ukanju}

Although there were other ethnicities of $u$ kanju in the early $17^{\text {th }}$ century, Chinese people made up the larger percentage of ukanju. The question is whether Chinese $u$ kanju were all Manchu slaves and whether they all fled from Manchuria. In other words, if any Chinese ukanju can be found fleeing towards the Manchus, such as in the aforementioned example of the Mongol ukanju, then the traditional view that Chinese ukanju were all escaped slaves of the Manchus would have to be dismissed. A record from 1631 in NGSYD depicts one such case regarding Chinese ukanju:

On the $3^{\text {rd }}$ and $4^{\text {th }}$ of the fifth month, 1631, three Chinese, riding horses, fled from Ning Yuan and Jin Zhou of Ming China to Manchuria. A wife, two pairs of slaves, cattle, and cloth were bestowed upon each of the three Chinese by the Manchu govern-

6 Mao Wen Lao Dang, 212. 
ment. $^{7}$ (emphasis mine)

Additionally, according to the same record from NGSYD, “"The Ming is now reinforcing and constructing a fortress in Da Ling He,' said the three ukanju." ${ }^{\prime \prime}$ (emphasis mine)

In this record, it is clear that in the $17^{\text {th }}$ century some Chinese ukanju were indeed fleeing to Manchuria rather than away from it. In addition, of all the rewards the three Han-Chinese ukanju received, the "two pairs of slaves" highlight the fact that these Han-Chinese ukanju were not slaves themselves, the reason being that slaves, belonging to the lowest class of society, were prohibited from owning other slaves. Based on the information extracted from this record, it is fair to say that not all Han-Chinese $u k a n j u$ were escaped Manchu slaves, and that the term ukanju should be redefined. Therefore, the view that Han-Chinese $u k a n j u$ were always escaped Manchu slaves is overturn. However, the original conundrum still stands: who exactly were the $u k a n j u$ ?

\section{3) Korean Ukanju}

In order to produce the exact definition of ukanju, I will now turn to ethnic Korean ukanju. Unlike the earlier two cases, I will use not only the Manchu archives, but also the Qing and Chosŏn archives written in classical Chinese.

According to the records from Qing Shi Lu, on $17^{\text {th }}$ of the eleventh month, 1638, two years after the second Manchu invasion, Chosŏn submitted a diplomatic document to the Manchu to express gratitude for the Qing "repatriation of Korean taoren." Although most of its content is written in classical Chinese, Qing Shi $L u$ is reliable since it is a classified official record to which ordinary people had no access. As a result, in this context, Korean taoren can be translated into Korean ukanju. In other

7 Nei Guo Shi Yuan Dang:1631, 124.

8 Nei Guo Shi Yuan Dang:1631, 124-5.

9 Qing Shi Lu, Nov. 17, 1638. 
words, Koreans were also included in the composition of the ukanju.

How were these Korean taoren, or ukanju, described in the Chosŏn archives? They were, according to a depiction of six Koreans in Tongmunhwigo (a compilation of diplomatic documents of the late Chosŏn), those who tried to cross the border and flee into Manchuria. ${ }^{10}$ Moreover, in NGSYD, these six Koreans were recorded as people who "attempted to flee into the country of higher status (in the tribute system)" (dergi gurun de ukame genehe). ${ }^{11}$ Here the phrase "ukame genehe" translates into "fled into." Therefore, given all of this information, the definition of the ukanju becomes clear: taoren, or ukanju, refers to someone who flees from their own country to another place, and that person is not always a slave or ethnically Han-Chinese.

\section{4) Manchu Ukanju (Warka ukanju)}

If (re)defining $u k a n j u$ as people who flee from their own country to another place is correct, we can assume that some cases involving Manchu ukanju should appear within the records, which they do. At this point this paper will examine the existence of Warka ukanju. ${ }^{12}$

The Warka ukanju were a group of ukanju composed of Warka Jurchens, who lived across the shores of the Tumen River, which divides present-day China, Russia, and North Korea. During the period in which Nurhaci - the founder of the Qing Dynasty - attempted to unify the Manchu empire, which included all the Jurchen tribes, the Warka were also targeted for subjugation. Since 1607, Nurhaci had requested Chosŏn to

10 Tong Wen Hui Kao (同文彙考) Vol. 24 (Taipei: Gui ting chu ban she, 1980), 231-2.

11 Nei Guo Shi Yuan Dang:1637-1638, 673.

12 Jang Jung-soo dealt with the relations between Warka Jurchen, Chien-chou Jurchen and Chosŏn, but he did not combine these Jurchens with the context of ukanju. See Jang Jung-soo, “Sŏnjodae Mal Yŏjin Pŏnho Rot'un(老土)ŭi Kŏnjuyŏjin Kwibuwa Chosŏnŭi Taeŭng (Submission of Boundary Jurchen, Lotun to Jianzhou Jurchen at the End of King Seonjo's Reign and Joseon's Response)," Chosŏnsidaesahakpo 78 (September 2016). 
repatriate the Warka numerous times. ${ }^{13}$ These requests, however, were all denied by the Chosŏn government, whose ruling elite worried that the repatriations would strengthen Nurhaci's bloc and that the new coalition of Jurchen would become an imminent threat to Chosŏn.

Hong Taiji, the successor of Nurhaci, also held this desire to reunify "the Warka diaspora." After trade missions to the Chosonn conducted by the Manchus encountered fifteen Warka in 1633, Hong Taiji, as his father did, asked Chosŏn to repatriate "the people of his race." ${ }^{14}$ In 1634, Hong Taiji sent a letter to King Injo of the Chosŏn, in which the future emperor of the Qing asked the king to repatriate "our Warka ukanju," (mini warkai $u k a n j u) .{ }^{15}$ Consequently, the phrases "the people of his race" and "our Warka ukanju" clearly prove ethnic Manchu ukanju also existed.

By analyzing the records from Manchu archives, we can now fully solve and understand the mysteries of the definition of ukanju and their ethnic composition. The ukanju were composed of Mongols, HanChinese, Koreans, and Manchus, and they were a group of people who fled from their own country to other places. Based on this reexamination of the definition of ukanju and their ethnic composition, this paper has proved the traditional view that the $u$ kanju were merely Chinese slaves who escaped from Manchu to be factually incorrect.

\section{The Social Status of Ukanju}

As this paper has shown above, ukanju should no longer be regarded as Chinese slaves of the Manchu. Some questions, however, still remain unanswered. Since we cannot presume that ukanju were always slaves, then what was the social status of the ukanju? I will continue to rely on the Manchu archives to answer these questions.

13 Chosŏnwangjosillok, March 17, 1607.

14 Chosŏnwangjosillok, February 29, 1634.

15 Nei Guo Shi Yuan Dang:1634, 343. 


\section{1) Upper Class: Aristocrats and Military Commanders}

Regardless of race, some high-ranking ukanju existed. These elite included Mongol or Manchu aristocrats and the military commanders of Ming or Chosŏn. We can accept a broad range of social status of these individuals since the definition of $u k a n j u$, as discussed above, is people who fled from their own countries rather than people who belonged to a specific social status or ethnicity. The cases that will be discussed below are primarily found in Tao Ren Dang, a Manchu archive which recorded cases regarding ukanju.

Many Mongol aristocrats fled to Manchuria in the $17^{\text {th }}$ century. They did not flee alone, but rather fled with their subjects. According to the records in Tao Ren Dang, on the sixth of the fourth month, 1629, two Tabunung (one of the ranks within the Mongol aristocracy), Toktohoi and Toolanto, fled from the Chahar Mongols to Manchuria with two hundred $u k a n j u$, including men and women. ${ }^{16}$ In this instance, the two hundred $u k a n j u$ were Mongols who fled from other Mongol tribes. However, the two Tabunung, despite not being described as counted within the two hundred people, were ukanju as well - fleeing from the Chahar Mongols and betraying the Mongolian lord and the last of the Borjigin clan of the Mongol Khans, Ligdan Khutugtu Khan. And they were not the only case. Before the two Tabunung fled from the Mongols, in the eleventh month of 1626, a beile (a second rank Mongolian aristocrat), named Durji of the Alaqcot tribe, fled from Chahar to Manchuria with more than one hundred of his subjects. ${ }^{17}$ Both of these cases clearly indicate that highranking Mongol ukanju indeed existed, most of whom were ignored by researchers due to misconceptions and incorrect definitions regarding ukanju.

Similarly, high-ranking Manchu ukanju can also be found within the archives. One widely-known example is the case of Asan. Asan, who

16 Tao Ren Dang, 55.

17 Tao Ren Dang, 3. 
joined Nurhaci's bloc with his father and later married one of Nurhaci's daughters, once attempted to flee to Ming China but was not accepted. ${ }^{18}$ Later, he attempted to flee a second time. In the eighth month of 1629, according to Tao Ren Dang, he fled to Ming China again as he was afraid that he would be punished for his brother's unforgivable mistake. ${ }^{19}$ Although he had fled from Manchuria to Ming China twice, Asan was not punished harshly - a picture vastly different from the cases of Chinese ukanju depicted by other historians. Instead, he became a Manchu aristocrat, whose title could be inherited by his son, resulting from his excellent performance in battle.

There were also high-ranking Korean $u$ kanju during the $17^{\text {th }}$ century. Han Úi (韓義) and Han Yun (韓潤) are exemplary cases. The two Han individuals and their father launched a coup in Chosŏn in 1623, dethroning the $15^{\text {th }}$ King of Chosonn. Unsatisfied by the rewards received following the coup, the Han family attempted to launch another coup in 1624 but failed. ${ }^{20}$ After their father was killed during the second coup, Han Üi and Han Yun fled to Manchuria to ask for refugee status and to be recognized as subjects of the Manchus. After being received by the Manchu government and appointed as military commanders, the two Hans were described as "Han Ǔi and Han Yun, who fled to us." They obtained numerous rewards, including wives, dwellings, farmland, and slaves. ${ }^{21}$ Therefore, we can also conclude that they were not slaves but military commanders. In 1627, when the Manchus launched the first invasion of Chosŏn, the two Hans made it possible for the Manchu army to quickly

18 Qin Ding Baqi Tong Zhi (欽定八旗通志) Vol. 29 (Taipei: Taiwan xue sheng shu ju, 1968), 11791-2.

19 Tao Ren Dang, 62-4.

20 The coup in 1624 is "Yi Kwal's rebellion." In terms of the detail of Yi Kwal's rebellion and Han Ǔi and Han Yun, see Han Myung-Ki, "Yi gwarŭi Nani Injodae Ch'oban Taenaeoe Chŏngch'aege Mich'in Yŏp'a (The Rebellion of Lee Gwal and the government of King Injo's Domestic and Foreign Policies)," Chŏnbuksahak 48 (April 2016).

21 Man Wen Lao Dang, 955. 
capture the Chosŏn capital.

The $u k a n j u$ also included high-ranking Han-Chinese. One Chinese tuse (a lower rank military commander) was assigned to Mao Wen-long, a significant general of the Ming who thwarted numerous Manchu invasions in Northeastern China. This tuse fled to Manchuria. The reason why he fled is not clear. According to Tao Ren Dang, before arriving in Manchuria, the tuse was jailed. After fleeing, the tuse received numerous rewards, including an attractive wife, food, cattle, silk clothing, boots, and five pairs of slaves. ${ }^{22}$ The quantity of rewards is no less than what the two Han individuals of the Chosonn obtained, which implies the high social status of this tuse.

\section{2) Lower Class: Slaves and Civilians}

Despite the existence of many upper-class ukanju, lower-class $u k a n j u$ still made up the majority. They were slaves and civilians. ${ }^{23}$ They came with their leaders or were captured by the Manchu army. Most importantly, these ukanju served as the catalysts for the two Manchu invasions of the Chosŏn.

Lower-class $u k a n j u$ were the biggest group among all $u k a n j u$. Although no clear statistics are available to show how many lower-class ukanju

22 Tao Ren Dang, 59-60.

23 As Pamela Crossley pointed out, the Manchus as one of the Tungusic peoples had a long tradition of slavery. By the time of Nurhaci, the slaves, many of whom were ethnic Chinese or Koreans, played main roles in agricultural production and household management. Apart from their contributions to agricultural and commercial developments of the Manchus, these slaves, as Frederic Wakeman, Jr. mentioned, also introduced technologies - such as how to make weapon or melt iron - to Manchuria under Nurhaci's rule. Pamela Kyle Crossley, The Manchus (Cambridge: Blackwell Publishers, 1996), 17; Gertraude Roth Li, "State Building before 1644," in The Cambridge History of China, Vol. 9, ed. Willard J. Peterson (Cambridge: Cambridge University Press, 2002), 21; Frederic Wakeman, Jr, The Great Enterprise: the Manchu Reconstruction of the Imperial Order in Seventeenth-Century China, Vol.1 (Berkeley: University of California Press, 1985), 45-8. 
existed during the $17^{\text {th }}$ century, the number can be estimated from diplomatic documents between Chosŏn, the Ming, and the Manchus. In 1625, King Injo of Chosŏn wrote a letter to the emperor of the Ming, requesting him to "send back the hundreds of thousands of Chinese who fled from Chosŏn to Ming China." 24 This request, however, was denied by the emperor, who said these "people who fled" could be used as resources to fight against the Manchus. In addition, on ninth of the twelfth month of, 1640, the Chosŏn government repatriated more than six hundred ukanju, including Chinese, Koreans, and Warkas to the Manchus. ${ }^{25}$ These records from diplomatic documents suggest great numbers of lower class ukanju, which should not be overlooked.

Some of the lower-class ukanju fled with their leaders. Unlike most aforementioned ukanju, who travelled in small groups and fled to Manchuria or other places alone, these groups of lower-class ukanju usually swelled to great numbers, and most importantly, followed political leaders. As for the case of the two Tabunung, Toktohoi and Toolanto, mentioned previously, these two individuals are categorized as upper-class ukanju. Furthermore, these two Mongol aristocrats fled from the Chahar Mongols to Manchuria with two hundred ukanju. That is to say, at least two hundred lower-class ukanju fled accompanying their leaders. The case of Alaqcot's beile, named Durji, also shows that numerous lower-class ukanju fled to Manchuria with him. Records suggest that he was accompanied by more than a hundred of his subjects.

Many lower-class $u k a n j u$, however, were captured by the Manchu army and treated as slaves. These were captured Koreans, Chinese, and Warkas. In 1627, after the first Manchu invasion of Chosŏn, the Manchu government requested that Chosŏn repatriate "Manchus, Han-Chinese, and captured Koreans who fled to Chosŏn."26 In addition, the Manchus sent more than 30,000 captured Koreans to Chosŏn to display their willingness to

24 Ming Shi Lu (明實錄), October 22, 1626.

25 Chosŏnwangjosillok, December 9, 1640.

26 Chosŏnwangjosillok, May 30, 1627. 
lay down arms. ${ }^{27}$ The reason the Manchus were concerned about these ukanju was that they could utilize ukanju to extort money from Chosŏn. In 1628, a Manchu official was irritated that, under most circumstances, the Chosŏn government not only displayed a negative attitude toward paying compensation for captured Koreans, but also let these people flee back to Chosŏn. ${ }^{28}$ All of these events imply that many ukanju were captured by the Manchu army and since these ukanju could be transferred via monetary transactions, they were similar to slaves.

The lower-class ukanju's significance is most clearly manifested in the two Manchu invasions of Chosŏn. Before the first invasion of Chosŏn by the Manchus in 1627, Hong Taiji, the second ruler of the Qing, argued that the Manchus were going to begin a war against Chosŏn because of the existence of the Ming general Mao Wen-long, whose army received many $u$ kanju fleeing from Manchuria and taking refuge on an island near Chosŏn. ${ }^{29}$ This attempt to avoid any increase in the amount of ukanju also echoed the Manchu request for repatriation of "Manchurians, Chinese, and captured Koreans who fled to Chosŏn" mentioned above. Moreover, in 1636, when discussing reasons for the Manchus to launch a second invasion of Chosŏn, Hong Taiji maintained that Chosŏn "breached the treaty between the two states by sending our ukanju to the Ming." After the second invasion, Chosŏn began returning numerous ukanju to the Manchus, including the previously mentioned case of over six hundred people in one day - the ninth of the twelfth month, 1640. Considering this evidence, we can note that lower-class ukanju played critical roles in the two Manchu invasions of Chosŏn.

27 Chosŏnwangjosillok, April 15, 1627.

28 Chosŏnwangjosillok, April 15, 1628.

29 Man Wen Lao Dang, 34.

30 Man Wen Lao Dang, 1471. 


\section{Border crossing, Ukanju, and Transition of the Northeast Asian Political Order in the 17th Century}

Up until this point, I have analyzed the racial composition and social position of the $u k a n j u$, as well as their role as a trigger in the two Manchu invasions of Chosŏn. In this section, I will further point out the importance of the practice of $u k a n j u$ border crossing and the relationship between these border crossings and transitions of the Northeast Asian political order during the 17 th century. I will specifically address the reversal of outcomes in battles between the Qing and the Ming, ukanju as "secret agents," the legal shift regarding state boundaries, and the act of fleeing in the Chosŏn legal code.

Ukanju border crossing reversed the tides of battles between the Qing (Manchu) and the Ming. Both upper-class and lower-class ukanju influenced the battles fought between the two parties. For example, two upperclass $u k a n j u$, Kong You-de and Geng Zhong-ming, had a huge influence on the war during the transition from the Ming to Qing. Commanding troops with cannons, Kong, a military officer of the Ming, was a key figure in the 1630s. In 1631, as his troops lacked field supplies, Kong assaulted Ming garrisons in Shandong province. Failing to repel the ensuing Ming counterattack, Kong and his subordinate, Geng, defected to the Qing becoming "the two commanders who betrayed the Ming and fled to us." ${ }^{31}$ As a result of Kong and Geng's defection, Manchu military forces were equipped with cannons and able to defeat the Ming in the Battle of Songjin in 1639. This incident helped to reverse the outcome of the war between the Ming and the Qing.

In the case of lower-class ukanju, the Manchu ukanju who fled to Pi Island, which was located near Chosŏn and controlled by Ming military forces, killed a Ming military commander, Liu Xing-zhi. Liu was a capricious military commander of the Ming, who once defected to the Qing but later re-defected to the Ming. In 1631, Liu betrayed the Ming yet again, purport-

31 Nei Guo Shi Yuan Dang: 1633, 92. 
ing that he would defect to the Qing. But this assertion seems untenable. According to Nei Guo Shi Yuan Dang, after hearing a rumor that Liu would kill all the Manchus on the island and re-defect to the Ming, the Manchu ukanju on Pi Island were shocked and incensed. They killed Liu in a preemptive attack and fled back to Manchuria. ${ }^{32}$ Due to the death of Liu, the military force on Pi Island quickly weakened. As a direct result, the Qing took Pi Island, an outpost of the Ming's military bastion, in 1637. Therefore, we can note that ukanju border crossing, such as the cases of Kong and Geng, as well as the death of Liu, was able to directly impact the outcomes of battles and the greater war between the Qing and the Ming.

Ukanju as border-crossers also served as "secret agents" during the 17th century. These ukanju transmitted military intelligence throughout the Ming, the Qing, and Chosŏn. In the fourth month of 1627, a Chinese ukanju who belonged to the Busuri of the Plain Blue Banner (正藍旗) fled to Dalinghe in the Ming, and later, returned back to Manchuria. The Chinese ukanju claimed that the Ming were reinforcing the fortresses at Jinzhou and Dalingho. ${ }^{33}$ In 1631, a military officer of Chosŏn on the state's northern border reported that three Chinese ukanju fled to Chosŏn. According to the three Chinese ukanju, Hong Taiji took an army comprised of more than 8,000 solders to assault Ningyuan. ${ }^{34}$ The Chosŏn government also tried to expose strategies employed by the Manchu army by interrogating Korean $u k a n j u$ who fled from Manchuria to Chosŏn. ${ }^{35} \mathrm{Be}$ yond these, plenty of other examples exist regarding the three governments ferreting out military intelligence of the ukanju, including the aforementioned case of Manchu ukanju claiming they killed Liu Xing-zhi on Pi Island. These facts all suggest that the ukanju border crossers served as de facto "secret agents" during 17th century conflicts.

The issues regarding ukanju border crossings also incited changes in

32 Nei Guo Shi Yuan Dang: 1631, 167-8.

33 Tao Ren Dang, 9.

34 Sŭngjŏnwŏnilgi (承政院日記), August 30, 1631.

35 Sŭngjŏnwŏnilgi, October 25, 1625; December 19, 1636. 
Chosŏn law on definitions of the boundary and the act of fleeing. In other words, these ukanju border crossers forced the Chosŏn government to rigorously regulate all illegal border crossings. In fact, during the $15^{\text {th }}$ century, Chosŏn had implemented a law, tomang (逃亡), to prohibit Koreans from fleeing Chosŏn territory. ${ }^{36}$ After being invaded twice and being requested by the Manchu to repatriate ukanju for several years, Chosŏn changed the law to pŏmwŏl (犯越). ${ }^{37}$ The discursive difference is crucial. Tomang means "fleeing," whereas pŏmwŏl suggests "invasion and border crossing." In this regard, the change in the law's language implies that the act of border crossing by ukanju had shaped a sense of territory and boundary, or state border, in pre-modern Asia. After the change, we can note a sharper sense of the physical distinction between Chosŏn and its neighbors, which cannot be said about Chosŏn during the reign of the Ming. This change in legal language clearly parallels the transition from Ming to Qing and the greater change of political order in Northeastern Asia during the $17^{\text {th }}$ century.

\section{Conclusion}

Ukanju, as a Manchu term, refers to a person or group of people who fled from their own country to another place. This definition is in direct contrast to the depictions of $u k a n j u$ used by many other historians, specifically the widely-held belief that $u k a n j u$ were Chinese slaves of the Manchu who attempted to flee. Largely overlooked evidence found in Manchu archives proves this traditional view to be untenable. The ukanju were composed of various ethnicities, such as Mongols, Chinese, Koreans, and Manchus. Furthermore, a plurality of social positions, including the upper class, such as Mongol aristocrats or Chinese, Manchu, and Korean military commanders, and lower-class individuals - slaves and civilians -

36 Kyŏngguktaejŏn (經國大典), 489-90.

37 Sinbosugyojimnok, 743. 
needs to be included in historical definitions of ukanju.

The complex composition of the ukanju reveals the pivotal roles these people played during the $17^{\text {th }}$ century. Some ukanju served as de facto "secret agents," who used the act of border crossing to receive and disclose military intelligence between the Manchus, the Ming, and the Chosŏn. Also, ukanju border crossing impacted regulations and legal language regarding illegal border crossing in Chosŏn's legal code. Most notably, the shift from "fleeing" to pŏmwŏl denotes a more specified physical boundary, or state border, between the Korean Peninsula and Mainland China. This change in attitudes towards a defined territory echoes with the transition from the Ming to the Qing and highlights the shift in the political order in Northeastern Asia during the $17^{\text {th }}$ century.

Perhaps most importantly, some ukanju even changed the outcomes of specific battles waged between the Ming and the Qing. Ukanju who fled to Chosŏn and to Pi Island instigated the two Manchu invasions of Chosŏn. Manchu ukanju on Pi Island even killed the Ming commander Liu Xing-zhi, undermining Ming military forces on the front line. Chinese military commanders, Kong You-de and Geng Zhong-ming, fled to Manchuria, empowered Manchu troops with cannons, and helped defeat the Ming in subsequent battles. As a result, the instances expounded upon in this research paper demonstrate that ukanju and the general act of border crossing not only reflect the changing political order of Northeastern Asia, but also played a greater role than traditional scholarship acknowledges in directly shaping political transitions during the $17^{\text {th }}$ century.

\section{References}

1. Crossley, Pamela Kyle. The Manchus. Cambridge: Blackwell Publishers, 1996.

2. Han, Myung-Ki. Chŏngmyo, Pyŏngja Horan'gwa Tong Asia (Studies of Manchu's invasions of Chosun Korea in 1627 and 1636 with east asian perspectives). Seoul: P'urŭn Yŏksa, 2009. 
3. Han, Myung-Ki. "Yi gwarŭi Nani Injodae Ch'oban Taenaeoe Chŏngch'aege Mich'in Yŏp'a (The Rebellion of Lee Gwal and the government of King Injo's Domestic and Foreign Policies)." Chŏnbuksahak 48 (April 2016): 93-136.

4. Jang, Jung-soo. "Sŏnjodae Mal Yŏjin Pŏnho Rot'un(老土)ŭi Kŏnjuyŏjin Kwibuwa Chosŏnŭi Taeŭng (Submission of Boundary Jurchen, Lotun to Jianzhou Jurchen at the End of King Seonjo's Reign and Joseon's Response).” Chosŏnsidaesahakpo 78 (September 2016): 7-49.

5. Li, Gertraude Roth. "State Building before 1644." In The Cambridge History of China, vol. 9, edited by Willard J. Peterson. Cambridge: Cambridge University Press, 2002.

6. Liu, Jia-ju (劉家駒). “Shun zhi nian jian de tao ren wen ti (順治年間 的逃人問題).” in Qing zhu li ji xian sheng qi shi sui lun wen ji 2 (慶 祝李濟先生七十歲論文集 下). Taibeishi: Qing hua xue bao she, 1967.

7. Tao, Xi-sheng (陶希聖). “Shun zhi chao de tao ren yu tou chong wen ti (順治朝的逃人及投充問題).” Shi Huo (食貨) 3, no. 11 (May 1936).

8. Wakeman Jr., Frederic. The Great Enterprise: the Manchu Reconstruction of the Imperial Order in Seventeenth-Century China, Vol.1. Berkeley: University of California Press, 1985.

9. Woo, Kyung-Sup. "Manjuro Kwihwahan Chosŏnindŭl." In Pömwolgwa Isan: Manjuro Kŏnnogan Chosoñindul (Illegal Crossing Border and Seperation), edited by Kim Seonmin. Incheon: Inha Taehakkyo Ch'ulp'anbu, 2010.

10. Wu, Bo-ya (労伯㛏). “Lun qing chu tao ren fa de she hui ying xisng (論清初逃人法的社會影響).” Qing Shi Lun Cong (清史論叢) 3 (Februay 1982).

11. Zhang, Jin-fan (张晋藩) and Guo Cheng-kang (郭成康). Qing ru guan qian guo jia fa lu zhi du shi (清入關前國家法律制度史). Shenyang: Liaoning ren min chu ban she, 1988. 
$<$ Abstract $>$

\section{Ukanju and the Changing Political Order of Northeastern Asia in the 17th Century}

For decades, historians defined the $u$ kanju, also known as taoren (逃人) in the Chinese-language archives of the Qing Dynasty (1644-1911A.C.), as the Manchu's ethnic Han-Chinese slaves or escapees. However, this definition fails to explain why ukanju served as the catalyst for the Manchu invasions of Chosŏn in 1627 and 1636 and why so many ukanju with considerable ethnic diversity emerged in the first half of the 17 th century. Also, the question of what roles the ukanju played in the Ming-Qing transition (1616-1644 A.C.) is still unexplored. In this essay, I will redefine $u k a n j u$ as, rather than merely slaves, a person or group of people who fled from their own country to another place (or crossed the borders). I will also point out the overlooked relationship between the $u$ kanju and the transition of the political order in Northeastern Asia during the 17th century including the reversal of outcomes in battles between the Qing and the Ming, the legal shift regarding state boundaries and the act of fleeing in the Chosŏn legal code. To achieve this goal, I will utilize Manchu archives as well as Qing and Chosŏn archives written in classical Chinese as the main sources of this essay. This study, therefore, contributes to Korean and Chinese history, international relations in pre-modern Northeastern Asia, and Manchu studies.

Keywords: $u k a n j u$, fleeing, border-crossing, international relations in premodern Northeastern Asia 


\section{〈국문초록〉}

\section{도인(ukanju)과 17 세기 북동아시아 국제질서의 변동}

이맹형 (컬럼비아대학교 동아시아언어문화학과 박사과정)

청나라 자료에 逃人이라고 기록되어 있는 Ukanju에 대하여 그간 역사학자들은 이들을 만주에서 도망간 漢人 노비로 인식해 왔다. 그러나 이러한 도인에 대한 정 의는 도인들이 왜 정묘 - 병자호란 기간에 집중적으로 출현했는지, 그리고 도인들 의 다양한 인종적 구성에 대한 설명을 제시하지 못했다. 또한 그들이 명 - 청 교체 기에 능동적 또는 수동적으로 어떤 역할을 했는지에 대한 연구도 거의 없었다. 본 연구는 도인을 노비만으로 인식하지 않고 "모국을 따나 다른 지역으로 건너간 사 람”으로 재정의하고, 그들의 월경 활동과 17세기 동북아시아 국제질서의 변동과의 연관성을 검토할 것이다. 즉, 그들이 명·청 대결 형세에 미친 영향과 조선의 월 경 도주 관련 법률의 수정에 어떤 영향을 미쳤는지를 탐구한다. 본고는 만주어 자 료 및 청나라와 조선의 한문 자료를 중심으로 하였다. 또한 한국사 뿐만 아니라, 중국사, 전근대 북동아시아 국제질서, 만주학 등의 관련 분야의 연구 발전에 기여 하고자 한다.

주제어: 도인(逃人), 도망, 월경, 전근대 동북아시아 국제관계 
